J. Natn. Sci. Coun. Sri.Lanka 198614 (1) : 83-94

\title{
POSSIBLE OCCURRENCE OF HALLOYSITE IN SRI LANKA
}

\author{
M. P. J. JAYAWARDANA \\ Department of Mining and Mineral Engineering, Faculty of Engineering, \\ University of Moratuwa, Katubedda, Moratuwa, Sri Lanka.
}

(Date of receipt : 07.11.85)

(Date of acceptance : 23.07.86)

\begin{abstract}
The yellowish and orangish brown concretions found very often in white crystalline limestones of Sri Lanka have been a mystery throughout. After a series of investigations, the author has identified them to consist mainly of the mineral halloysite. Halloysite is used as a bleaching clay and a catalyst. This paper discusses different properties of the mineral which enabled the author to identify it.
\end{abstract}

\section{Introduction}

Crystalline limestones are very common in Sri Lanka. Figure 1 shows the occurrences of crystalline limestones and dolomites throughout the island. They are mainly found in the Precambrian rocks and are connected with the Charnockite-Metasedimentary belt.

In most of these crystalline limestones, yellowish and orangish brown coloured, irregularly shaped masses and concretions are a common sight. But they were not given any mineralogical identification and no research in this connection has been conducted previously.

The author carried out a programme of research and thoroughly investigated these masses and concretions. Samples were collected mainly from three locations i.e. Koslanda, Hakgala and Teldeniya. Figure 2 shows a crystalline limestone outcrop (in white) at Koslanda where these were abundant.

\subsection{Literaturé Review}

Halloysite was first found in Belgium in the Angleur limestones near Liege. During the same period this mineral was discovered in a number of places in the USSR.

Some of its properties were described by Winchell in 1939 as follows: Chemistry - a silicate, soluble in HF; Specific Gravity - 2.1; Habit - clayey; Cleavage - none; In thin section - colourless, isotropic, refractive index $1.47-1.57$. 


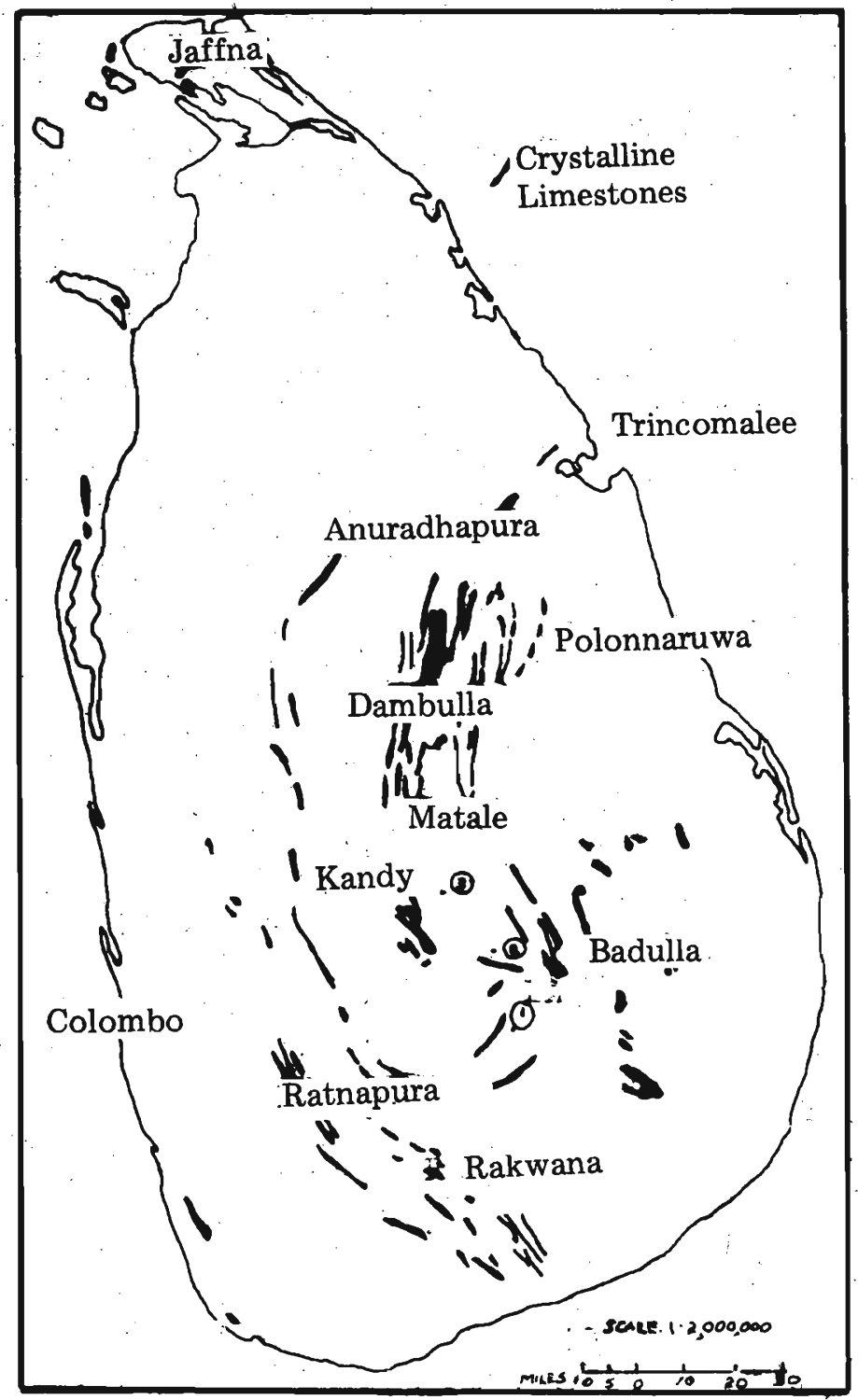

Figure 1. Map showing crystalline limestones in Sri Lanka. 


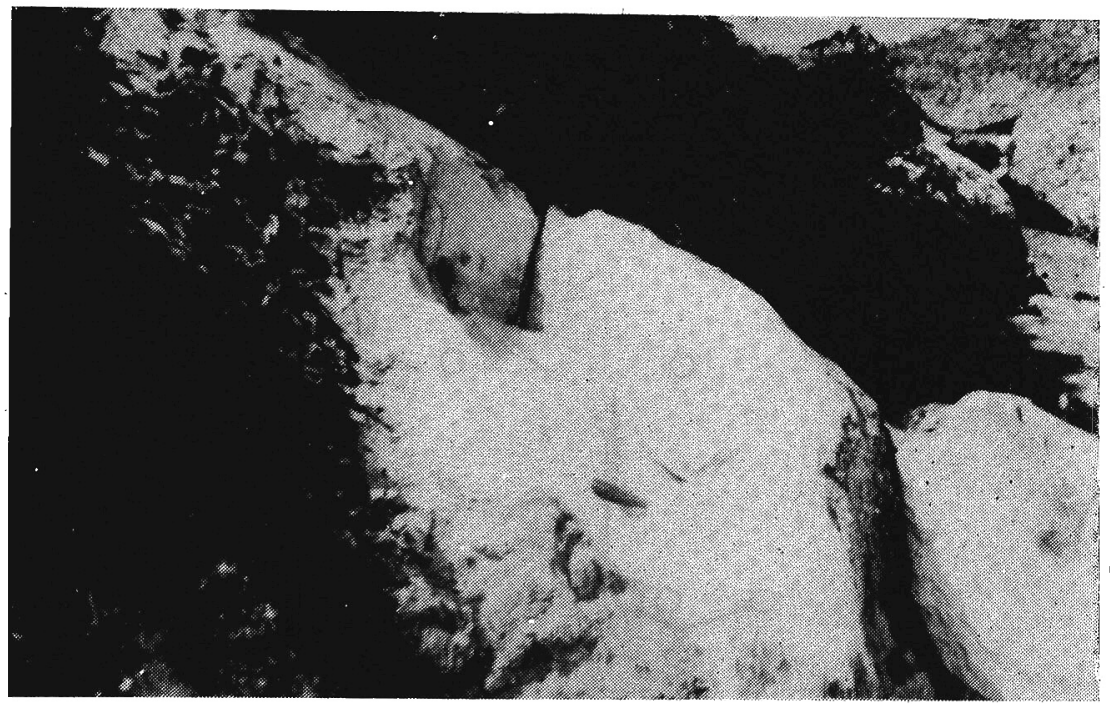

Figure 2. A crystalline limestone outcrop at Koslanda.

$\mathrm{Read}^{4}$ studied the mineral further and described it as a mineral having a chemical composition close to kaolinite but containing more hydroxyl ions. He proposed the chemical formula $\mathrm{Al}_{4} \mathrm{Si}_{4} \mathrm{O}_{6}(\mathrm{OH})_{16}$.

Read further testified that the yellow or red clay called bole, found mainly in Italy includes types that are impure Halloysite. Also Lithomarge was identified by Read as a white, yellow or reddish clay consisting of Kaolinite and Halloysite.

Later in 1963, van Olphen ${ }^{5}$ states that unlike Kaolinite, Halloysite contains interlayer water and upon heating it is irreversibly dehydrated. The dehydrated form is sometimes called Metahalloysite.

But according to Mason, Halloysite is one of the polymorphs of Kaolinite and he gives it the same chemical formula as for Kaolinite. Yet. there is a difference he maintains : Halloysite is made up of an irregular sequence of Kaolin layers.

Betekhtin $^{2}$ has different observations. He groups Halloysite along with Garnierite. According to Betekhtin, the major difference between Kaolinite and Halloysite is that Halloysite contains two extra molecules of water. The crystal structure of Halloysite, according to him, is given in Figure 3. 


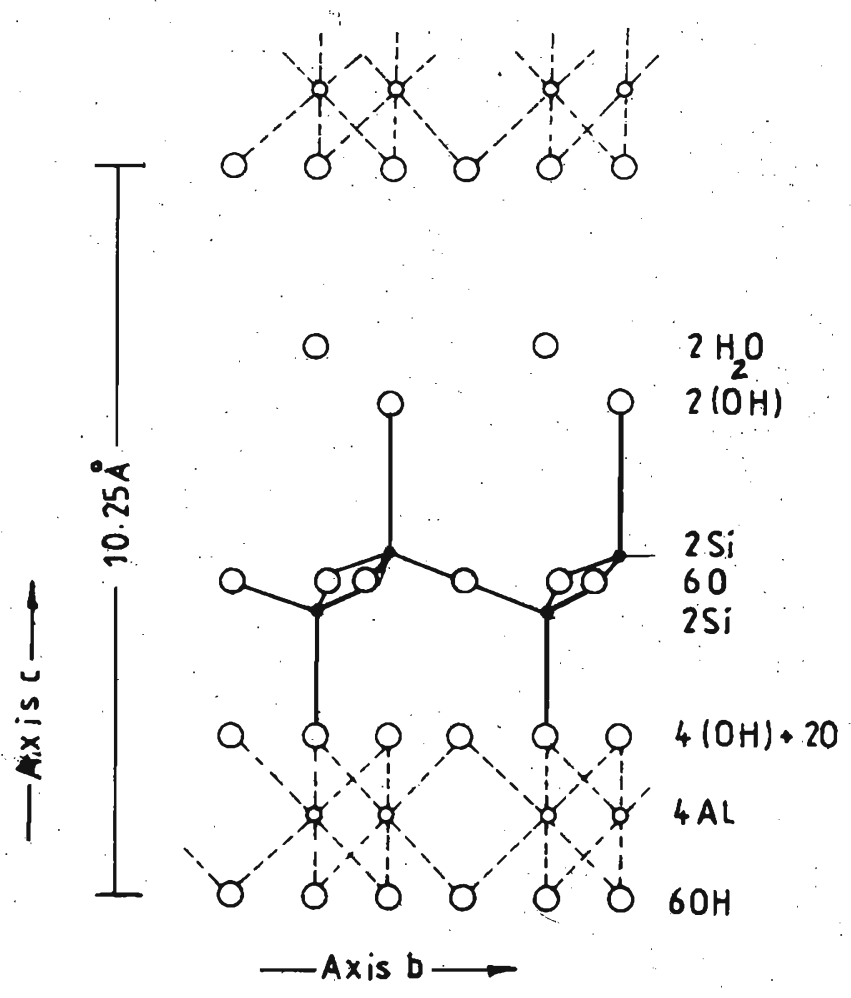

Figure 3. Crystal structure of Halloysite after Betekhtin.

\section{Investigation and Observations}

In this study samples were taken from the three locations Koslanda, Hakgala and Teldeniya which are marked as $1,2 \& 3$ respectively in Figure 1. Presence of the mineral in crystalline limestone hand specimens is shown in Figures $4,5 \& 6$. The white background is crystalline limestone and the dark patches are the mineral concretions.

The mineral was carefully separated from crystalline limestone and its physical properties were determined. The optical properties were obtained by using thin sections. Mineral grains were observed also under reflected light. Figure 7 gives a view of the mineral under the mineragraphic microscope with a magnification of 85 times. The physical properties obtained in these investigation are given in Table 1. 


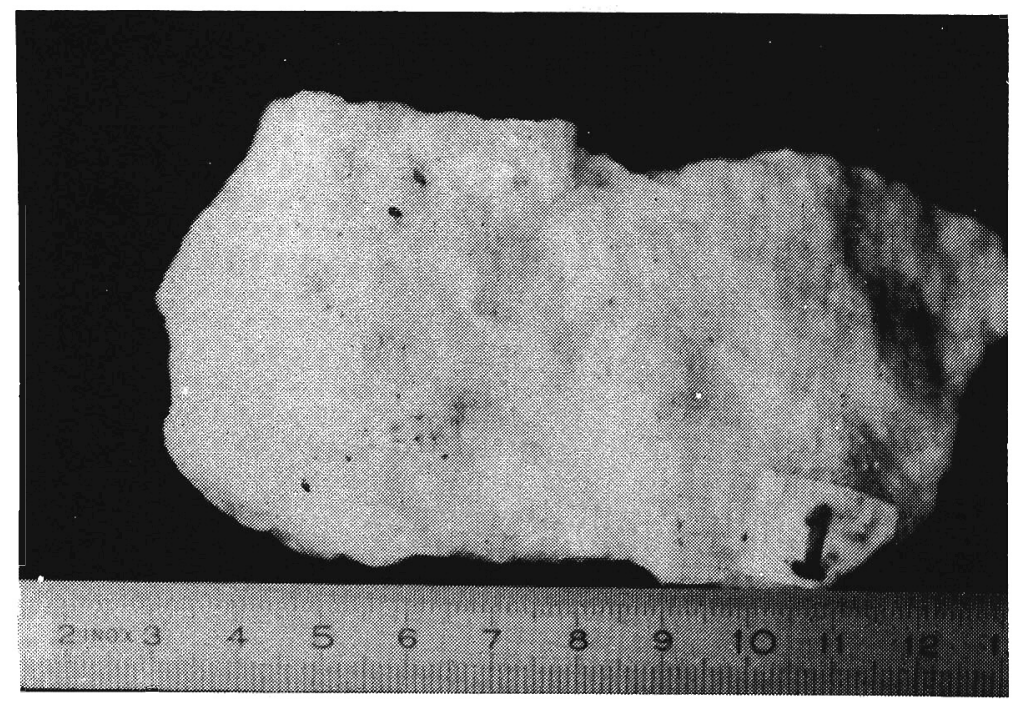

Figure 4. Halloysite in limestone (Koslanda).

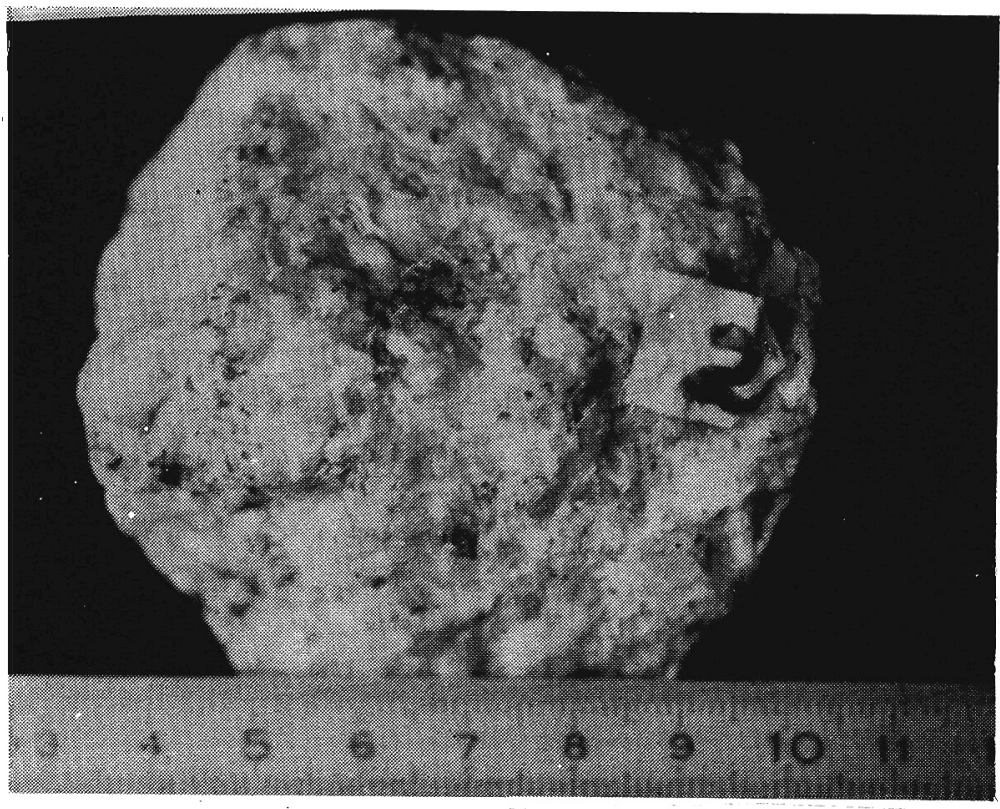

Figure 5. Halloysite in limestone (Hakgala). 


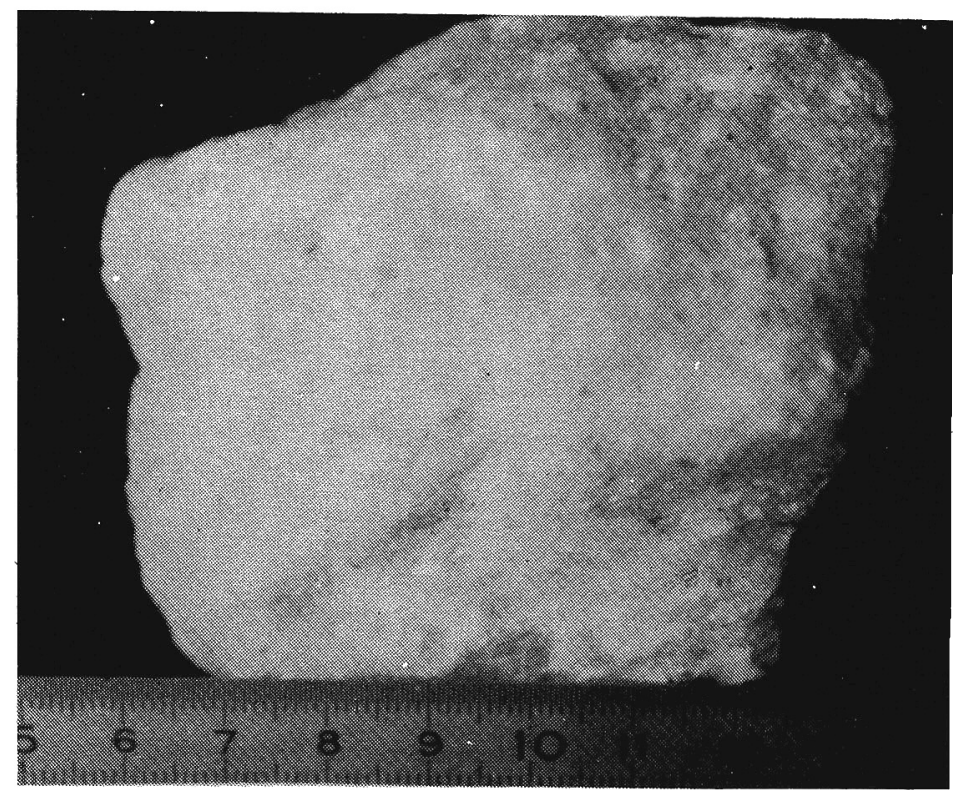

Figure 6. Halloysite in limestone (Teldeniya).

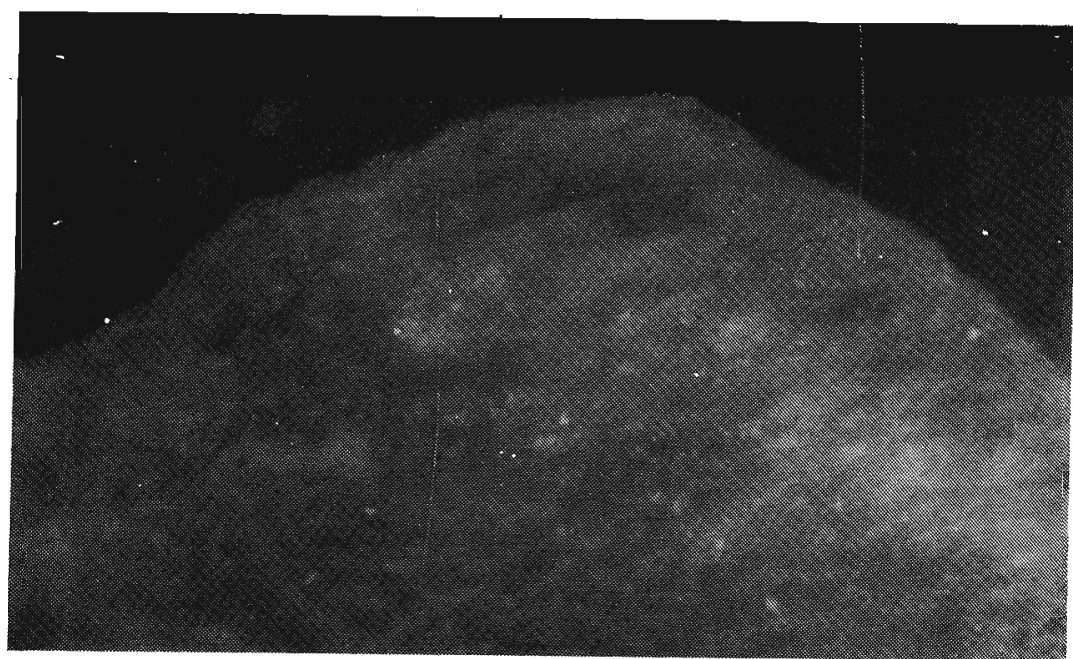

Figure 7. Halloysite under reflected light (85X). 


\begin{tabular}{llll}
\hline & \multicolumn{3}{c}{ Location } \\
\cline { 2 - 4 } Property & Koslanda & Hakgala & Teldeniya \\
\hline Colour & Yellowish & $\begin{array}{l}\text { Orangish } \\
\text { brown }\end{array}$ & $\begin{array}{l}\text { Orangish } \\
\text { brown }\end{array}$ \\
Lustre & Dull & Dull & Dull \\
& waxy & Earthy & Waxy \\
System & Monoclinic & Monoclinic & Monoclinic \\
Refractive Index & 1.54 & 1.55 & 1.54 \\
Hardness & 2 & 2 & 2 \\
Specific Gravity & 2.21 & 2.21 & 2.20 \\
& & & \\
\hline
\end{tabular}

Table 1. Physical properties

Differential Thermal Analysis of the mineral and Kaolinite was carried out. Figure 8 shows differential thermal analysis curves of Kaolinite.

$\mathrm{X}-$ Ray Diffraction Analysis was also carried out. The diffractogram thus obtained is produced in Figure 9. The Unit cells parameters according to the diffractogram of the mineral are $5.05 \mathrm{~A}^{\circ} ., 8.9 \mathrm{~A}^{\mathrm{O}}$ and $10.1 \mathrm{~A}^{\mathrm{O}}$. Electron microscopy was also utilized. The electronmicrographs of the mineral were taken and Figure 8 shows an electronmicrograph with a magnification of 2000 times.

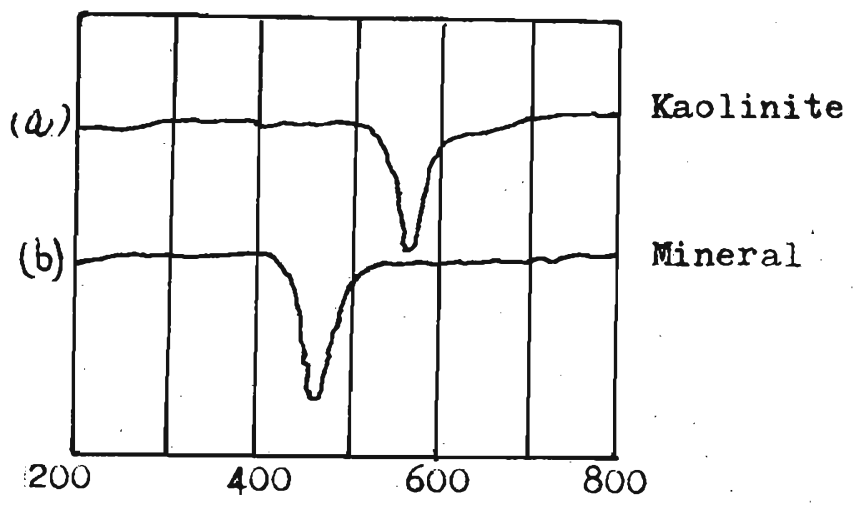

Figure 8. Differential Thermal Analysis Curves of the Mineral and Kaolinite. 


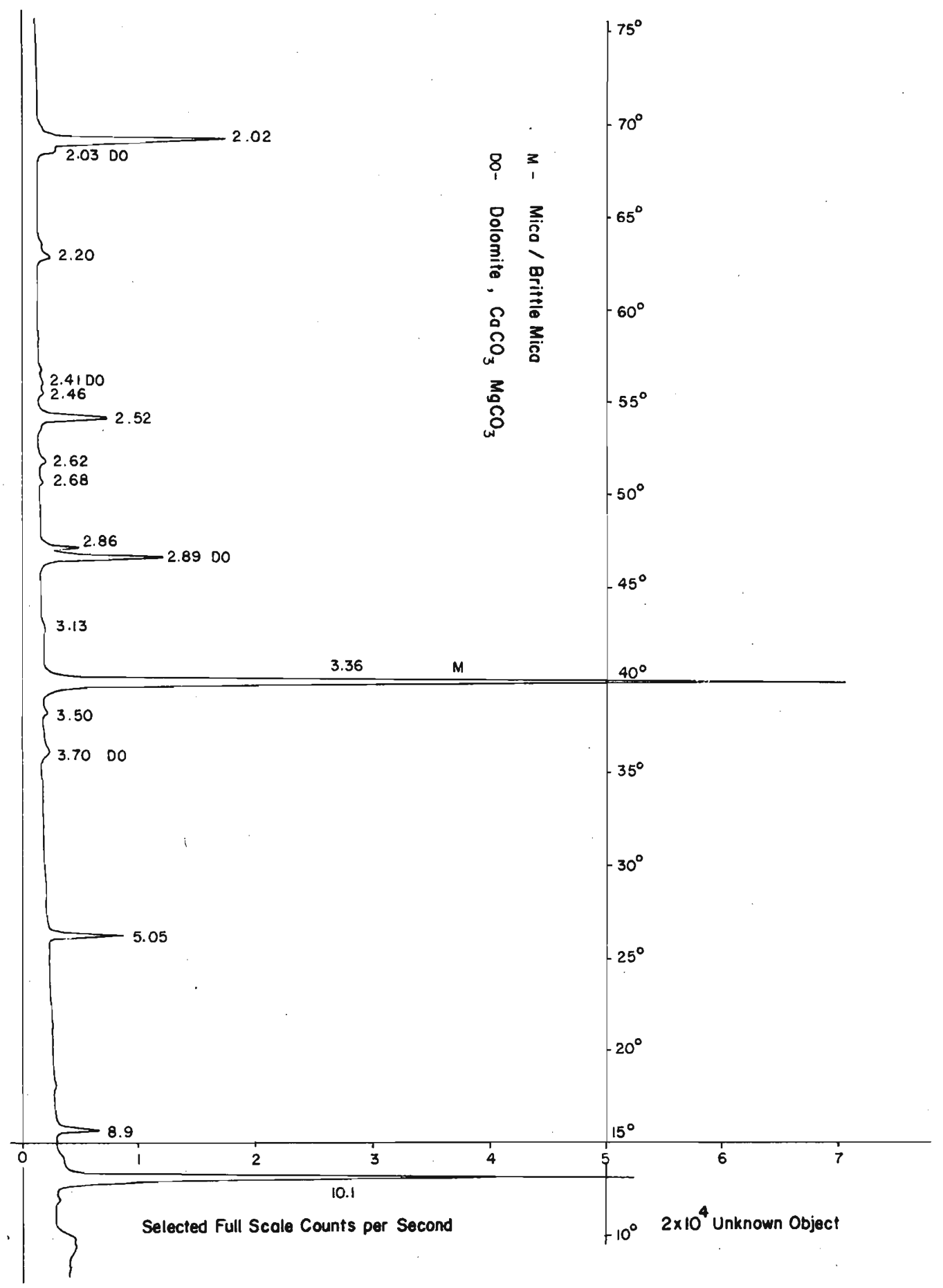

Figure 9. $X$ Ray Diffractogram of the Mineral 


\section{Discussion of Results}

The physical properties obtained and given in Table 1 did not have much variation according to the location. The physical properties suggest the mineral can be Halloysite. The chemical analysis gives the mean values for the oxides in the mineral as: $\mathrm{Al}_{2} \mathrm{O}_{3}-34.4 \%$; $\mathrm{SiO}_{2}-40.5 \% ; \mathrm{H}_{2} \mathrm{O}-24 . .4 \%$.

Iron oxides $-0.3 \% ; \mathrm{MgO}-0.2 \%$; $\mathrm{CaO}-0.2 \%$. The water content differs from that of Kaolinite substantially.

Of the numerous formulae presented by various authors for Halloysite the most suitable would be : $\mathrm{Al}_{4}\left(\mathrm{Si}_{4} \mathrm{O}_{10}\right)(\mathrm{OH})_{8} \cdot 4 \mathrm{H}_{2} \mathrm{O}$

The structure of the mineral is given in Figure 3.

The colour of the mineral could be attributed to the presence of iron oxides. In the mineral grains, the innermost core contained only very pale yellow coloured material and the colour became more and more intense from centre towards the periphery.

The actual lustre of the mineral should be considered as waxy since that is the lustre observed on fresh surfaces. It becomes dull when the mineral is allowed to remain in the open air.

The considerably low specific gravity can be attributed to the high content of water.

The differential thermal analysis curves show that the endothermic peak in the mineral at $450^{\circ} \mathrm{C}$ clearly differentiates it from Kaolinite which has this peak at $550^{\circ} \mathrm{C}$ and clearly identifies the mineral as Halloysite.

$\mathrm{X}$-Ray Diffraction analysis of the mineral prove beyond any doubt that the mineral is Halloysite. According to standard text books the unit cell parameters are $5.2 \mathrm{~A}^{\mathrm{O}}, 8.9 \mathrm{~A}^{\circ}$ and $10.1 \mathrm{~A}^{\mathrm{O}}$ for Halloysite.

The electron micrographs show that the individual crystals have dome like forms. The rod - like shape which most authors attribute to Halloysite under the electron microscope is obtained only when finely dispersed.

Chemical analysis of the mineral were also carried out. Table 2 shows the results of the chemical analyses of the three given locations. 


\begin{tabular}{lccc}
\hline & \multicolumn{3}{c}{ Location } \\
\cline { 2 - 4 } Oxide & Koslanda & Hakgala & Teldeniya \\
\hline $\mathrm{Al}_{2} \mathrm{O}_{3}$ & 34.3 & $34 . j$ & 34.5 \\
$\mathrm{SiO}_{2}$ & 40.6 & 40.5 & 40.4 \\
$\mathrm{H}_{2} \mathrm{O}$ & 24.5 & 24.4 & 24.4 \\
$\mathrm{Fe}_{2} \mathrm{O}_{3}$ & 0.2 & 0.3 & 0.3 \\
$\mathrm{FeO}_{\mathrm{MgO}}$ & 0.2 & & 0.3 \\
$\mathrm{CaO}$ & 0.2 & 0.0 & 0.1 \\
\hline
\end{tabular}

Table 2. Chemical composition

\section{Conclusion and Recommendations}

As the above discussion clarifies the mineral in the crystalline limestones as yellowish and orangish brown concretions masses is definitely Halloysite.

This study was limited to one series of rocks. The mineral Halloysite reported by the author is confined to the crystalline limestones of the Highland series only.

Presence of Halloysite need not be confined to the crystalline limestones or to the Highland series at that. Therefore further research in this direction might prove worthwhile.

Halloysite, obtained in large quantities could be used as a bleaching clay and a catalyst. Therefore other than the pure academic interest, attention should be given to prospecting for Halloysite.

\section{References}

.1. BATES, R. L. (1969) Geology of the Industrial Rocks and Minerals. Dover Publications Inc., New York. p. 120.

2. BETEKHTIN, A. G. (1975) A Course of Mineralogy. Peace Publishers, Moscow. pp. $538-546$.

3. MASON, B. (1968) Elements of Mineralogy, International Edition. W. H. Freeman \& Co., San Francisco and London. pp. $436-443$. 
4. READ, H. H. (1947) Rutleys Elements of Mineralogy. 24th Edition.

Thomas Murby \& Co., London. pp $412-414$.

5. VAN OLPHEN, H. (1963) Clay Colloidal Cbemistry: Interscience Publishers, New York. pp. $71-79$.

6. WINCHELL, A. N. (1939) Elements of Optical Mineralogy. John Wiley \& Sons Inc. New York. pp. $136-137$. 